\title{
子どもの遊びの分析を通した活動の構造的・生態学的モデルの提案 A STRUCTURAL AND ECOLOGICAL MODEL OF ACTIVITY
BY ANALYZING CHILDREN'S PLAY
}

\author{
尹 俊 到*，木多道宏**，鈴木 毅**，閔 丙 吴*** \\ Jundo YUN, Michihiro KITA, Takeshi SUZUKI \\ and Byungho MIN
}

\begin{abstract}
Observations of children playing in the neighborhoods of six towns in Japan present alternative views to the transaction of children's activities and their neighborhood environment. They indicate that children's activities are of such a complicated nature that each has in it a countable number of sub-activities called individual actions. Activity is a composite of these small actions and can successfully be defined by a structure of the interrelationships among these actions. This activity structure was analyzed and defined in terms of three dimensions-sequential relationship, dependence interaction, and dominance configuration. Data also indicates that children's activity is dependent on environment because its individual actions interact with environmental resources. This view demands an analysis that takes the interaction of individual action and environmental resource as a unit of analysis and as a way to operationalize human activity.
\end{abstract}

Keywords : Children, Play, Individual Action, Activity, Activity System, Resource

$$
\text { 子ども、遊び、個別行為、活動、活動システム、資源 }
$$

\section{1. 研究の背景と目的}

本研究は、人閒の行動と環境との本質的な関係を分析するために、 (1)行動の分析単位として、微細な「個別行為(Individual Action)」と、複数 の個別行為群から構成される「活動(Activity)」の概念を抽出・提示すると ともに、(2)活動を構成する個別行為間の関係性である「活動システム (Activity System)」注1)、1)、2)を読み取ることを目的とする。さらに、(3)個別 行為の発現に必要な資源(環境要素) 注2)、3)についての考察も試みる。

子どもの遊びを発現させるために必須である要因(空間、時間、仲閒 $)^{4)}$ を研究することに加えて、人間の行動がどのような構造であり、その構造 がどのような方式で作用するのか、また研究者や計画者は、どのように 人間の行動を規定し、建築・環境デザインのための行動セッティング5)を 提示するのかに対する理論的パースペクティブが必要であると考える。

\section{2. 既往研究の検討}

\section{1. 環境と人间の行娌との関係}

環境と人間の相互関係に関する研究は様々な理論注3)、63方提唱されて きた。例えば、心理学者アルトマンは行動科学研究とデザインの役割・ 目標を行動過程 (Behavioral Processes)、場所(Places)、設計プロセス (Design Processes)に分類・分析しており、また、環境行動学者ムーアは 環境行動研究における主要な次元・内容の変遷について、場面・場所 (Setting/Places)、利用者集団 (User Groups)、行動現象・概念 (Behavioral Phenomena/Concepts)などを詳細に分けて研究している。
その中で、子どもの遊びに関する研究は、環境行動学、または人間 行動学分野における従来からの中心的な研究テーマであるだけでなく、 近年、住居学及び団地計画研究分野においても重要な位置を占めて (る7)、8)。子どもの研究についても、子どもの遊びを発達学的な視点で

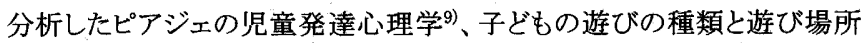
を詳細に分析したロビンムーアの研究 ${ }^{10)} 、$ 遊びの環境要素を通じて子ど もの遊び構造を詳細に分析した研究11)な゙が見られる。

このように、場所、利用者集団、遊び環境要素などの環境と人間との 関係について詳細に分類・分析した研究は数多く見られる。一方、人間環境研究の中で最も基本になる人間の行動そのものを微細な単位に 分析して、環境要素が行動の発現過程とどのような関係にあるのかといら 課題を系統的に解明した研究は未だ少ないといえる。その中で、人間の 行動を微細なスケールから分析しているユリー・ブロンフェンブレンナー は、子どもの発達過程を生態学的な観点から分析するため、巨視的活動 (Molar Activity) と微視的行動 (Molecular Behavior)の概念 ${ }^{12)}$ を提案し、 環境が人間に与える影響について研究している。

以上のように、人間一環境の関係を考察するための最も根本的な人間 の行動を分析するためは、個別行為、活動、活動システム、そして資源 (Resource)などが重要な概念注4)、13) として関わっている。活動は個別行 為から構成されており、活動の性格はそれがどのような個別行為群から 構成され、またその構造の中でお互いにどのように作用しているか(4.3
*1 大阪大学大学院工学研究科建築工学専攻 博士後期課程

*2. 大阪大学大学院工学研究科建築工学専攻，助教授

*3 覀州大学建築学部 教授(韓国)
$\mathrm{Ph} . \mathrm{D}$. Student, Department of Architectural Engineering, Graduate School of Engineering, Osaka University

Assoc. Prof., Department of Architectural Engineering, Graduate School of Engineering, Osaka University

Prof., Department of Architecture, Ajou University (Korea) 
個別行為の脈絡、依存関係、重要度)によって決まると言える。活動を 個別行為の集合として見ると、環境と直接的に相互作用寸る単位は、 活動ではなくて個別行為であると言える。言い換えれば、個別行為が 環境から影響を受けて活動を構成するといらことである。また、このような 個別行為を通じて資源(環境要素)の分析が可能になると考えられる。

\section{2 人間の行動の類型化の問題}

行動科学の根本的な目標は「実証的理論」を樹立することと、その現 象を記述し、説明することである。そして人間の行動に対する多数の研究 は、多様な人間の行動をどのように類型化(Typology)するかという過程の 作業に依存する。類型化は莫大な資料を整理可能な形態で要約する 過程と言えるが、資料の本質を重視する一方でそのディテールを切り捨 てる一種の資料縮約作業(Data Reduction)でもある。また、研究者は資料 とデータをどの程度まで解釈的(Interpretive)に判断するのかを考慮する。

多くの既往研究で見られる類型化の過程では、実際の観察で得られる 子どもの遊びに対する豊かな資料が何種類かの日常的な活動に変換さ れて縮約されている。研究者は、行動の類型を分類、定義するため、 行動類型間の境界が曖昧なまま、独断的判断と理論的構造に依拠して 資料を縮約している。このような資料の縮約の過程によっては、複雑な 人間の行動をありのまま表現することができないと言える。

例えば、「休息」、「対話」、「徘䧃」、「ボール遊び(Ball Play)」、「乗り物 遊び(Wheel Play)」、「道具・もの遊び(Object Play)」などがあるが、このよう な方式で類型化と用語の定義注5)をした研究では、その後すべての分析 段階でこのような単純化された用語を使うことで分析結果が導かれている。

しかし、このような類型化や用語の操作的定義(Operational Definition) が理論的な利便性や研究分析の効率の側面で有効なこともあるが、子ど もの遊びの構造や環境との複雑な関倸を十分に表現することができない ため、明確な意味が伝わりにくいと考えられる。

\section{3. 研究の方法}

\section{1 調查の対象}

人間の行動がどのような構造によって構成され、その構造がどのような 方式で作用して人間の行動の性格を規定するのかに関わる理論的視角 を考察し、また、行動が一定の構造と過程によって形成されることを明ら かにするために、多様な行動が観察される調査対象地を選定する必要が ある。そこで、資源の種類や配㯰の異なる地域のバリエーションを得るた め、計画的団地 (ニュータウン) と非計画的な居住地 (既成市街地)の $2 つ$ の区分を設定し、それぞれについて、(1)市街地 (千里ニュータウン竹見 台団地、大阪市生野区密集市街地)、(2)子どもが容易に接近できる自然 要素が含まれる場所(ニュータウン内の公園、都市内の水辺空間)、(3)道 路(ニュータウン内の歩行者専用路、既成市街地内の道路)を調查対象 地として選択した。その結果、図1の通り、6地域を調査対象地とした。 なお、以上については、既往研究4)、10)、14)、15)を参考に、子どもの遊びを 多く観察できる地域・場所の候補を設定し、候補地に対する予備調查注6) を行うことにより、調查対象地域として絞り込むこととした。

各対象地に対して平日、祝日の各1回ずつ合計 12 回の観察調査を 実施した（竹見台団地: 2003年11月3日・6日、生野区:2004年11月 2 日・ 3 日、北千里公園: 2004 年 6 月 10 日・ 13 日、鴨川: 2004 年 11 月 16 日 $\cdot 23$ 日、 多摩ニュータウン街路: 2004 年5月 31 日・6月 2 日、空堀地区街路: 2004 年 10月 24 日・28日)。以上の調查より、281の遊びの事例を収集した。

\section{2 調查の方法}

定性的な研究(Qualitative Research) ${ }^{16}$ ) 調査方法は、単純に資料を
得る実用的技法とその手続きを意味するだけではなく、資料の創出過程 における知的・分析的・解釈的な検討も含まれる。したがって、調查対象 地で行う観察は、半構造的(Semi Structured)でまた、緩く構造化された (Loosely Structured)観察方法とした。そして、活動の詳細な内容と、その 変化に対する観察に焦点を合わせた。また、どのような要因が一つの活 動の発現に必要なのか、活動がどのような要因に依拠してどのような過程 を経て発現されるのかを細密に記録した。このためには、より包括的な観 察、脈絡を考慮した観察が必要であるため、活動の時間別の変化や集 団(行為者・重要な意味をもつ他者) 注7)、17)の変化を連続的に記録した。

観察対象地域が広くて観察時間は制限されているため、調査方法とし て観察経路法(Observation Route Method)注8)、18)、19)を用い、観察内容を 行動プロット図(Behavior Mapping)に記録した。そして、この調查方法の 短所である一定時間の間に発生する活動の変化を把握するために、 必要性に応じて追跡観察(Tracking Observation)を行うとともに、物理的 要素の使用を確認するために、子どもの遊びが終るまで待って痕跡観察 (Observing Physical Traces)調査も実施した。

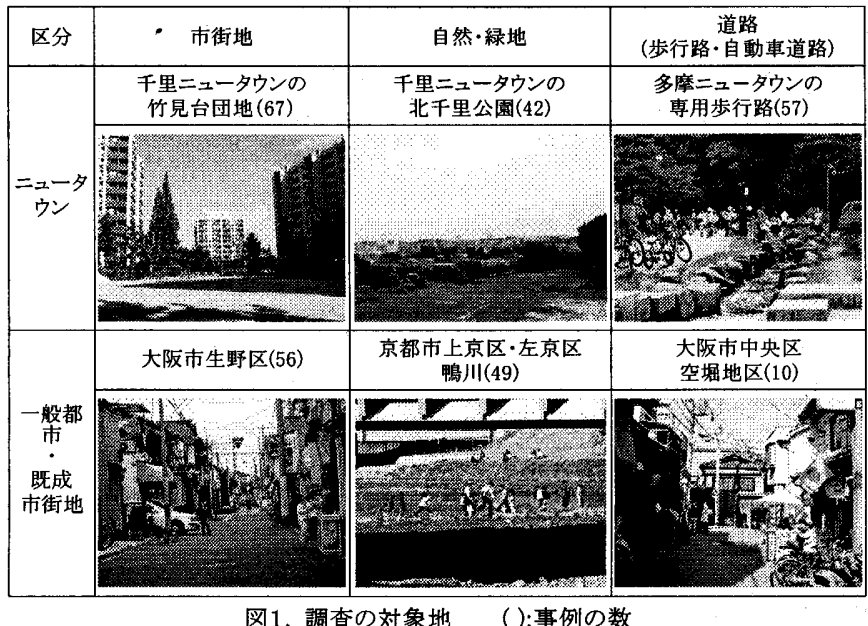

\section{4. 個別行為}

\section{1 活動の分析単位としての個別行為の提案}

観察された活動を、現場における豊かで多様なそのままの状態で理解 し、その活動によって表出される現実世界を正確に解き明かそうとする時、 人間の活動を単一の分析単位(Unit of Analysis)として扱うには、人間の 活動はあまりにも複雑である。さらに、既往研究における、人間の活動を 類型化する際の問題のように、建築環境の中で発現する複雑な人間の 活動の本質は、研究者による類型化の過程で損失される恐れがある。

従って、環境を小さな単位(Micro-environment)に区別した分析が有効 なように、観察される人間の活動の複雑性を説明するには、人間の活動 を多数の個別的な小行為(a Set of Individual Action)によって分析する ことが有効であると考えられる。さらに、このような微細単位への分類に よって、活動の発現に必要な資源 (環境要素)を分析することが容易に なると期待される。

\section{2 個別行為の意味と分析の基準}

1）個別行為は、誰にでも観察でき、判別できる客観的現象である。 態度 (Attitude)、感情 (Feeling)、思考(Thought)のような概念とは異なる 観察によって判別される現象である。つまり、個別行為は観察状況を 総合した非具体的な概念、または全体論的な用語(Holistic Definition)で 表現された概念的現象ではない、具体的で客観的な現象だと言える。

2）個別行為は、観察できる人間の活動の最小単位である。最小単位 
であるとは、各個別行為がそれぞれ自分なりの固有な意味を持っている ことである。したがって、活動発現のための動作(Motion)には固有な意味 がないから個別行為ではない。

例えば、「木の上に登って、集まって話す」といら事例では、「木に登る」、 「木の枝に座る、「集まっている」、「話す」などが、それぞれに自分なりの 意味を持っているので、分析の基準の問題は“それが何か”と意味を提示 できる段階まで限定されなければならない。したがって木を登るために 木を見る、話す時相手の顔を見るために頭を回すなどの動作は個別 行為の部分または、機能的な要素にはなるが、それだけでは行為として の意味がないから個別行為ではない。

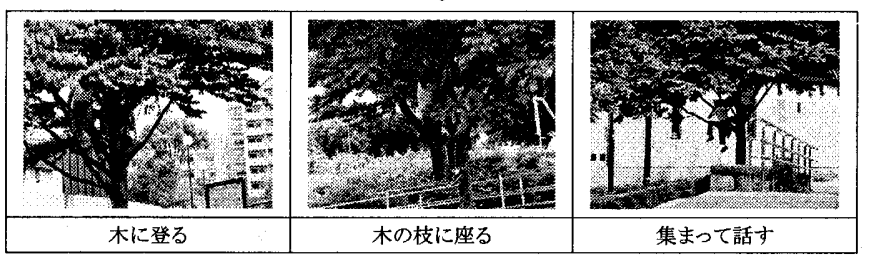

図2. 個別行為の分析の例

3）個別行為は、活動を構成する組み合わせが可能な単位である。 一つの行為の意味は、他の行為の意味と組み合わさって、一つの活動と して完成される。したがって、このような行為群が一定の相互関係をもつ ことによって、一つの活動は全体的な意味を持つようになる。また、活動 の中において、ある行為が従前の意味と脈絡から離れて、他の行為と 組み合わさり新しい脈絡に含まれると、その活動は従前とは違った意味を 持った活動に変換されると考えられる。例えば、次のような「座る」という 個別行為に、「ポータブルゲームをする」、「水遊び」、「話す」などの他の 個別行為が加えられることによって、活動の意味が変わるために、これら の活動は異なるものとして区別される。

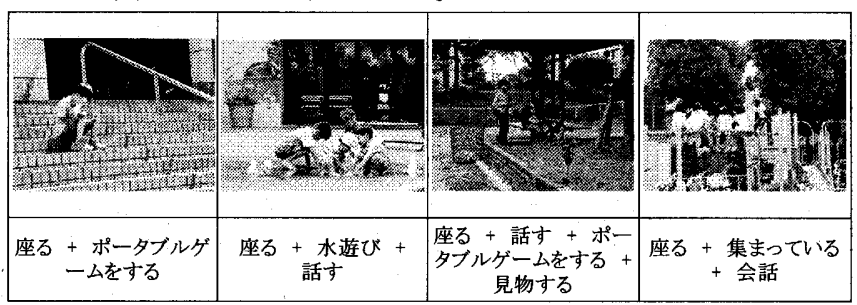

図3、「座る」個別行為と様々な個別行為との組み合わせ

4）個別行為は、行為者間に見られる行為を一つの分析単位にしなけ ればならない。観察できる最小単位としての独立的な個別行為は、一人 の場合でも発生するが、多くの場合が 2 人以上の相互関係によって成立 する。例えば、「誰がより遠くに石を投げることができるか仲閒と競争する」 と「お互いにボールを投げ合う(キャッチボールをする)」が成立するため には、複数の行為者の相互関係が必要不可欠であるため、一つの個別 行為として分析しなければならないと考えられる。

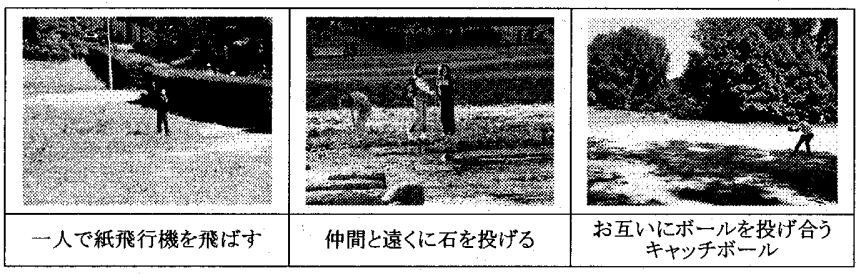

図4. 行為者の相互関係による活動の例

5）組職的な活動は、一つの個別行為として分析することができる。 組職的活動といらのは、「サッカー」「「ードゲーム」のような規則とパター ンがあり、参加者の役目、活動目的が繰り返し発生する活動である。この ような組職的活動は、多くの行為群が一つの規則とパターンによって
形成・存在するといえる。したがってこのような活動の中で規則とパターン から外れた行為が行われると、その組職的活動の意味は失われ、全く 異なる意味の活動になる。慣習的な組職活動は全体を一つの個別行為 として扱わなければならないと考えられる。

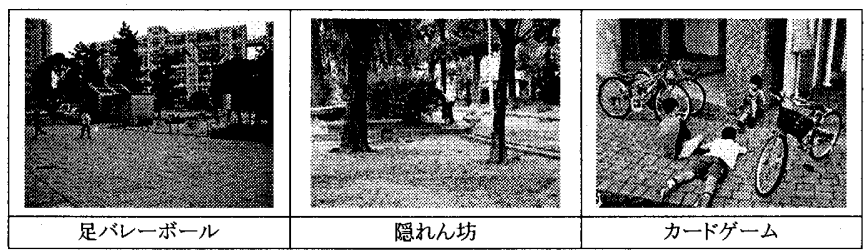

図5.組職的活動であるゲームの例

6）個別行為の分析により、資源を特定することができる。人間の活動 は、個別行為の脈絡と構造から発生すると考えられるため、活動を構成 する個別行為の区分は、各個別行為がお互いにどのような資源(環境 要素)を活用しているのかによって区分される。したがって、個別行為の 分析を、資源の分析方法として利用できると考えられる。

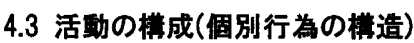

人間の活動が個別行為から構成されるということは、一つの活動が 様々な個別行為の組み合わせによって構成されていることを意味する。 したがって、活動の性格・意味を規定するためには、この組み合わせの 関係を定義しなければならない。活動を構成する個別行為の組み合わせ の関係を大きく三つに分けて分析した。

1) 個別行為群が、時間的にどのように発生するのか(行為脈絡)

2) 個別行為群が、どのような相互依存関係をなしているのか(相互 依存の関係)

3）個別行為群において、個別行為の重要度または支配力にどのよう な差があるのか(支配行為と付随行為)

\subsection{1 调別行為の脈絡}

観察される活動における個別行為の発生過程は、時間的脈絡の観点 から、大きく次の $2 つ の$ 特徵に分類することができる。

一つの活動において、多数の個別行為が同時多発的に発生する場合 であり、もう一つは、複数の個別行為が時間差をともなって連続的に、 すなわち時系列的に観察される場合である。両者はさらに、個別行為の 間に依存関係がある場合 (機能的・社会的)とない場合 (連結構造)に 分かれる。例えば、個別行為群が時系列的脈絡で依存関係にない事例 は、先に発生する行為と次に起きる行為が、時差を置いて順次発生する 場合を指す。

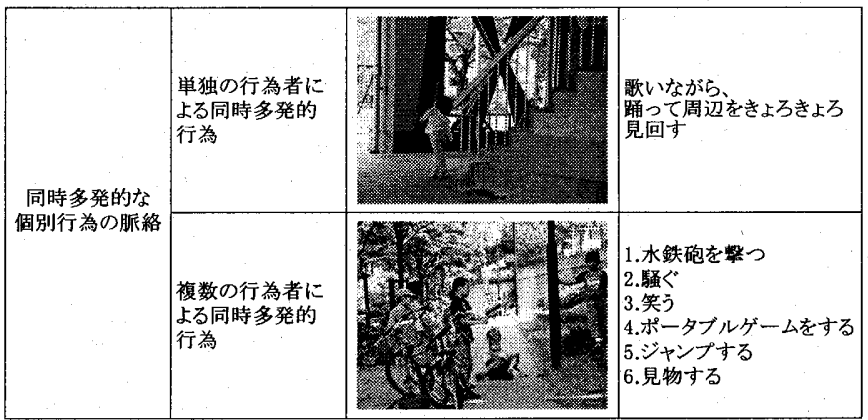

図6. 同時多発的な個別行為の脈絡

1）同時多発的な個別行為は、行為者が単独または 2 人以上の協力に よって同時に行為を行う場合と、一つの活動集団に属した複数の行為者 が独立的にそれぞれ異なる行為をすることで、一つの活動に多くの行為 が同時発生する場合がある。

2）時系列的な個別行為の発生は、先に発生した行為が次に発生する 
行為と関連があり、また後の行為が先の行為に依存する、すなわち行為 が相互時差的、機能的に依存する場合である。そして個別行為群の 機能的依存が重要ではない状態では、活動の行為が時間差をともなって 順に発生することもある。

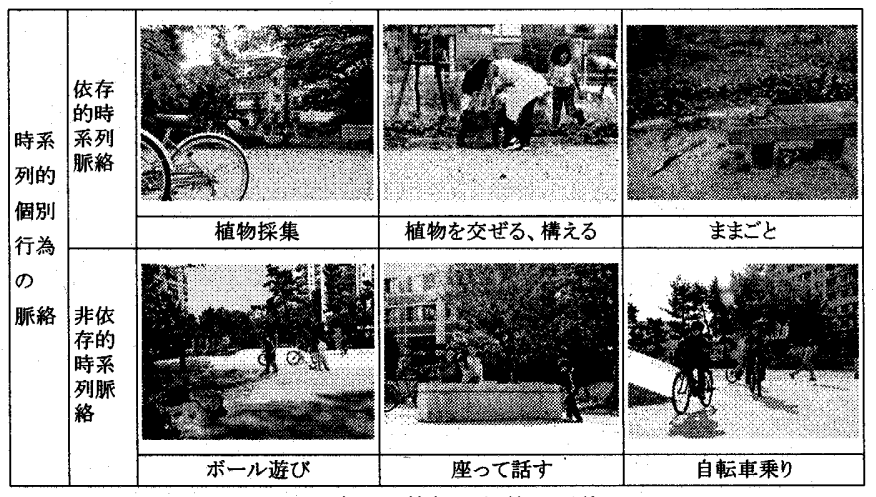

図7. 時柔列的個別行為の脈絡

\subsection{2 调別行為の相互依存と組み合わせの泟係}

活動を構成する個別行為群は、機能的、社会的に互いに依存しなが ら発生する。機能的な依存とは、一つの個別行為の発生過程に他の 行為が機能的に必要な場合、一つの行為の発生によって他の行為が 機能的に附随する場合である。例えば、「野球」のような規則と役目のある ゲームは、「ボールを投げる」、「走る」などの個別的な行為が、互いに 機能的に依存しながら発生するものである。

また、観察される個別行為群が、一定の社会関倸にある活動集団に おいて独立的に発生する場合は、社会的な依存関係にあると言える。 一つの活動集団に属する2以上の行為者またはグループが独立的な 行為をする場合を指し、例えば、図8の事例の通り、一定の社会的関係に ある7人の子どもが、一定の距離の特別な位置を選んで集まる活動 (Social Gathering)に見られる。

「座る小、立つ小、話す小、見る小、「すべり台を上がる小、風船を吹く」 などの個別行為が 2 人以上の行為者によって独立的に進行されており、 これらが一つの社会的集団の中で行われていることが分かる。行為者が 彼らの内部の社会的関係とその意図に対する認識を共有しており、同時 にその社会的グループ内の他の行為者が行う個別行為をお互いに意識 して、相互反応する状況が見られる。

\begin{tabular}{|l|l|l|l|}
\hline \multicolumn{3}{|c|}{ 個别行為の機能的依存関係 } & 個别行為の社会的依存関係 \\
\hline & & & \\
\hline
\end{tabular}

$$
\text { 図8. 依存関係 }
$$

\subsection{3 调別行為の垔要度:支罚行為之付随行為}

各々の個別行為は独自の意味を有しているため、それらが活動に対し て持つ意味や重要度には差がある。複雑な活動において、ある1つの 行為が明確に重要な意味をもつ場合、その行為を活動に対する支配 行為と呼ぶ。活動の意味と性格を定義する時、支配行為は支配的な 影響力を持つことになる。逆に、活動に対して、大きな支配力を持たない 行為を、付随行為とする。例えば、子どもたちが小川に「木の葉を浮かべ る」活動は、その前に「地面を観察する」、「木の葉を拾う、「笑いながら 話す」などの付随行為から構成されていると言える。

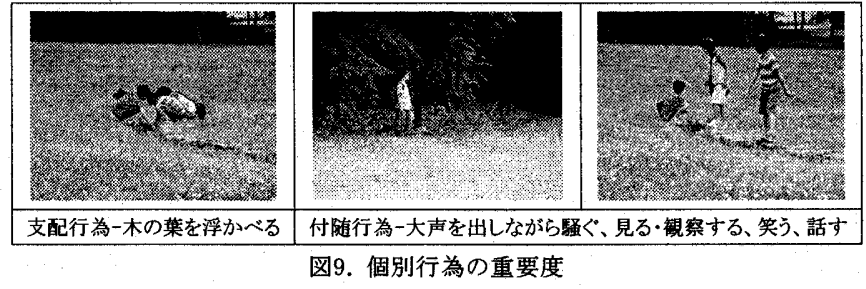

したがって、時閒的脈絡、依存関係、重要度によって、一つの活動を 構成する個別行為群の関係を整理できる。

表1. 活動と個別行為との関係

\begin{tabular}{|c|c|c|c|c|}
\hline \multirow{2}{*}{$\begin{array}{l}\text { 時間的 } \\
\text { 連繶性 }\end{array}$} & \multirow{2}{*}{$\begin{array}{l}\text { 重要度 } \\
(*)\end{array}$} & \multicolumn{3}{|c|}{ 関係性 } \\
\hline & & 機能的依存 & 社会的依存 & 連結構造 \\
\hline \multirow[t]{2}{*}{ 同時精造 } & 同等 & $\begin{array}{l}\text { 同等な重要度の個別 } \\
\text { 行為が機能的に依存し } \\
\text { て同時進行(ボール遊 } \\
\text { びのたに投げる、走 } \\
\text { り回る行為が機能的依 } \\
\text { 存関係で結合) }\end{array}$ & $\begin{array}{l}\text { 同等な重要度の個別行 } \\
\text { 為你社会的に依存して } \\
\text { 同時進行 }\end{array}$ & $\begin{array}{l}\text { 同等な重要度の個別行 } \\
\text { 為が同時連結(食べなが } \\
\text { ら会話する) }\end{array}$ \\
\hline & 従属 & $\begin{array}{l}\text { 同時進行する機能的 } \\
\text { 依存行為が } 1 \text { の行為 } \\
\text { に従属(話しながら宿題 } \\
\text { をする) }\end{array}$ & $\begin{array}{l}\text { 同時進行する社会的依 } \\
\text { 存行為が } 1 \text { つの行為に } \\
\text { 社会的に従属(手を取り } \\
\text { 合って自転車に乗る) } \\
\end{array}$ & $\begin{array}{l}\text { 同時進行する連結行為 } \\
\text { の中で1つが特に重要 } \\
\text { な場合(話しながらポー } \\
\text { タブルゲームをする) } \\
\end{array}$ \\
\hline \multirow{2}{*}{$\begin{array}{c}\text { 時系列的 } \\
\text { 構造 }\end{array}$} & 同等 & $\begin{array}{l}\text { 多数の重要な個別行 } \\
\text { 為が機能的に依存して } \\
\text { 時系列に隻行(自転車 } \\
\text { に乗って公園に行き、 } \\
\text { いたずらをする) }\end{array}$ & $\begin{array}{l}\text { 多数の重要な個別行為 } \\
\text { が社会的に依存して時 } \\
\text { 系列に進行 }(* *)\end{array}$ & 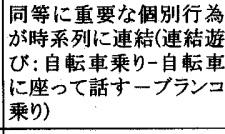 \\
\hline & 従属 & $\begin{array}{l}\text { 機能的依存関係にあ } \\
\text { り、時采列に倠行する } \\
\text { 個別行為が、1つの行 } \\
\text { 為に徒属(水を持ってく } \\
\text { る、木葉を拾うこと一ま } \\
\text { まごと) }\end{array}$ & $\begin{array}{l}\text { 社会的依存関係にあり } \\
\text { 時系列進行する個別行 } \\
\text { 為が } 1 \text { つの行為に従属 } \\
(* *)\end{array}$ & $\begin{array}{l}\text { 連結莓造にある個別行 } \\
\text { 為の内、重要な行為に } \\
\text { 他の行為が從属(ウオオ } \\
\text { ミングップ後サッカー } \\
\text { をする) }\end{array}$ \\
\hline
\end{tabular}

*:「同等」は全ての個別行為の重要度が同等の場合を指し、個別行為群の中で一つの個別 行為が無くなっても活動の棰造は変わらない。また「従属」は、個別行為の重要度に差がある 場合を指し、個別行為群の中で支配行為に付随行為が従属され、支配行為が無くなれば付 随行為も無くなることを意味する。

** : 実際は、観察されなかったが、理論的に分類されたもの。

\section{5. 活勡の分析及ひ实証}

\section{1 固別行為の程類(表2)}

以上の原則によって、281の遊び事例から1295の個別行為を抽出し、 全ての個別行為を33カテゴリー、110種類に分類した。1つの活動におい て、平均4.61件の個別行為が見られた。最も多く観察された個別行為は 集団による活動の多くに基本的に含まれている「騷ぐ・笑う」、「会話」、 「座る」、立つ」などである。

\section{2 代表的活为の分類(衰3)}

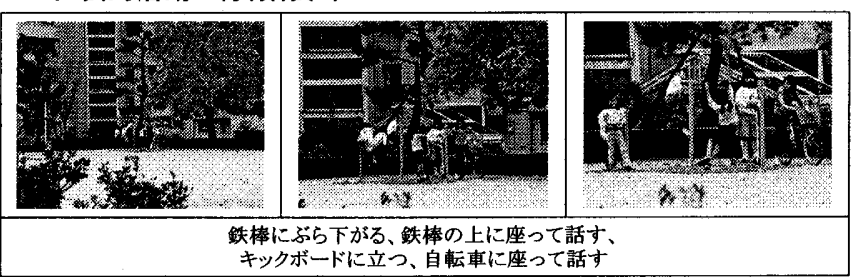

活動を分析する際には、活動脈絡を構成する個別行為をその活動の 要素として定義し、要素間の構造の分析により活動を理解する構造的 (Structural)、生態学的(Ecological)現象学の視点がなければ、分析を 通して活動の本質が大きく歪曲されることもある。図10のような活動の例 では、多数の子どもが「鉄棒にぶら下がる」、鉄棒の上に座って話す」、 「キックボードに立つ」、自転車に座って話す」などの活動が時系列的か つ同時多発的に発生していることが分かる。一定の社会関係にある活動 集団の中で行われるこれらの活動を個別行為のレベルで分析する場合、 「会話」、「立つ」、「座る(道具)」などの社会的性格の強い行為が含まれる

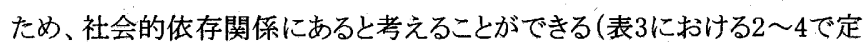
義）このように観察される個別的要素を包括的に分析しなければ、この 
活動は鉄棒を利用した「遊具遊び」、乗り物遊び」などのように、特定要 素だけで代表・定義して分析することになる。よって、個別行為の概念を 通じた活動の分析は、活動の性格の明確化に役立つと言える。しかし、こ のような個別行為の分類の多様性は、活動を理論的に再構成する際の 類型化(Typification)過程、活動と活動場所との関係、活動と資源(環境 要素)との関倸などに対して、分析的混乱を与える余地もある。そのため、 個別行為の本質を外れない範囲で、少数の個別行為群で縮約作業を試 み、33カテゴリーの個別行為と、14種類の代表活動類型に分類した。個 別行為の縮約作業と活動類型に際して、次のように三つの点に注意した。

1）このような個別行為の縮約作業には、研究者(分析者)による解釈の 介入が不可避であり、一つの類型化の過程において資料の本質がある 程度変質されることは避けられない。

\begin{tabular}{|c|c|c|c|}
\hline \# & 個別行為 & 割合 & 個別行為の分類 \\
\hline 1 & 歩く & $52(4.02 \%)$ & 歩く \\
\hline 2 & うろうろする & $37(2.86 \%)$ & うろうろする \\
\hline 3 & 立っ & $89(6.87 \%)$ & 立つ \\
\hline 4 & 走り回る、立ち飛びをする & $67(5.17 \%)$ & 走る \\
\hline 5 & $\begin{array}{l}\text { かかがんで座る、地面に座る、地面に横たわ } \\
\text { る、正座する }\end{array}$ & $82(6.33 \%)$ & 座る01(身体) \\
\hline 6 & $\begin{array}{l}\text { 椅子・ベンチ・平床に座る、段・石・手すりな } \\
\text { どに座る、眠り・横になる、自転車・バイクに } \\
\text { 座る、遊具に座る }\end{array}$ & $47(3.63 \%)$ & 座る 02(道具) \\
\hline 7 & \begin{tabular}{|l|} 
壁・手すりに寄りかかる、彫刻物・遊具に寄り \\
かかる
\end{tabular} & $38(2.93 \%)$ & 奇りかかる \\
\hline 8 & 話す、会話をする、議論·討議をする & $109(8.42 \%)$ & 会話 \\
\hline 9 & 䭷ぐ、笑う、大声を出す & $139(10,73 \%)$ & 騷ぐ・笑う \\
\hline 10 & 見物する & $93(7.18 \%)$ & 見物 \\
\hline 11 & きょろきょろ見回す & $15(1.16 \%)$ & きょろきょろ見回す \\
\hline 12 & 見る、観察する、触る & $61(4.71 \%)$ & 見る・観察する \\
\hline 13 & 投げる、砂を撒く、履き物を投げる、睎る & $41(3.17 \%)$ & 投价る・踣る \\
\hline 14 & 持つ & $64(4.94 \%)$ & 荷物を持つ \\
\hline 15 & $\begin{array}{l}\text { つかむ(服、胸ぐら)、押す、引き寄せる・あげ } \\
\text { る、地面にころころ転がる、振る、握る、転が } \\
\text { す、移す }\end{array}$ & $24(1.85 \%)$ & 身体をぶつけ合う \\
\hline 16 & 鬼ごっこ、隠れん坊、ジャンケングーム & $12(0.93 \%)$ & 身体ゲーム \\
\hline 17 & 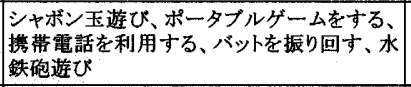 & $23(1.78 \%)$ & 既製玩具遊び \\
\hline 18 & 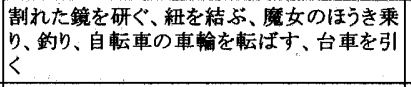 & $19(1.47 \%)$ & 類似玩具遊び \\
\hline 19 & 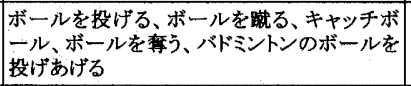 & $37(2.86 \%)$ & ボール遊び \\
\hline 20 & $\begin{array}{l}\text { 野球ゲーム、足バレーボールゲーム、キック } \\
\text { ベースボールグーム、バスケットボールダー } \\
\text { ム、お手玉ゲーム }\end{array}$ & $12(0.93 \%)$ & 球技ゲーム． \\
\hline 21 & カードゲーム & $6(0.46 \%)$ & カードグーム \\
\hline 22 & ローラーブレイド乗り、キックボード乗り & $4(0.31 \%)$ & $\begin{array}{l}\text { ローラープレイド, } \\
\text { キックボード乗り }\end{array}$ \\
\hline 23 & $\begin{array}{l}\text { 支えてもらって自転車に乗る、ひとり乗り、 } \\
\text { 二人乗り、競争して乗る }\end{array}$ & $43(3.32 \%)$ & 自転車乗り \\
\hline 24 & 椅子に乗る、ベビーカーに乗る & $2(0.15 \%)$ & 類似乗り物に乗る \\
\hline 25 & $\begin{array}{l}\text { ぶらんこ乗り、すべり台乗り、鉄棒で回る、網 } \\
\text { を渡る、飛び石を渡る、平均台を被る、 } \\
\text { うんていにふらら下がる }\end{array}$ & $32(2.47 \%)$ & 遊具遊び \\
\hline 26 & 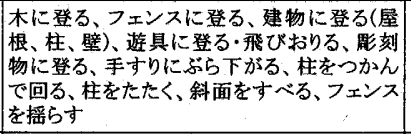 & $26(2.01 \%)$ & 類似遊具遊び \\
\hline 27 & ままごと、猫の真似をする & $4(0.31 \%)$ & ままごと \\
\hline 28 & 䡔築遊び(家造り)、もの操作遊び & $4(0.31 \%)$ & 操作·構築 \\
\hline 29 & \begin{tabular}{|l|} 
噴水台で遊ぶ、どぶんどぶんと水にとび込 \\
む、水の下を通り抜ける、浮かべる
\end{tabular} & $27(2.08 \%)$ & 水遊び \\
\hline 30 & 土遊び、石遊び、砂遊び & $16(1.24 \%)$ & 土·石・砂遊び \\
\hline 31 & 動物・虫を採集、植物採集、落ち葉を混ぜる & $42(3.24 \%)$ & 動植物遊び \\
\hline 32 & $\begin{array}{l}\text { 本を読む、自転車を修理する、宿題をする、 } \\
\text { 周辺を整理する }\end{array}$ & $13(1.00 \%)$ & 作業·目的行為 \\
\hline 33 & 食べる、飲む & $15(1.16 \%)$ & 飲食 \\
\hline 合部 & 110 & $1295(100 \%)$ & \\
\hline
\end{tabular}

2)このような曖昧さにも関わらず、全体的な活動の意味が、個別行為 の縮約過程を通じて大きく歪曲されることを少しでも減らすことができると 考える。つまり、従来の類型化過程の焦点だった活動自体ではなく、 分析水準を一段階具体化した個別行為の分析を通じて、活動の本質を 外れない範囲で分析できると言える。

3）活動類型別にどのような個別行為の発生頻度が高く、活動がどの ような個別行為群で構成されているのかを判断することが、活動を定義・ 区分するために必要だと言える。

\section{表 3. 個別行為を通した代表的活動の分類}

\begin{tabular}{|c|c|c|c|c|c|}
\hline$\#$ & 重要な個別行為 & $\begin{array}{c}\text { 脈絡·俵存· } \\
\text { 支配行為 } \\
\end{array}$ & 活動 & 頻度 & 割合(\%) \\
\hline 1 & $\begin{array}{l}\text { 歩く、うろうろする、見る・ } \\
\text { 観察する、荷物を持つ、 } \\
\text { 会話 }\end{array}$ & \multirow{5}{*}{$\begin{array}{l}\text { 同時多発的発 } \\
\text { 生·非㑈存的 } \\
\text { 時系列発生· } \\
\text { 社会的依存関 } \\
\text { 係·支配行為 } \\
\text { なL }\end{array}$} & 歩く・俳䧃·うろうろする & 16 & 5.69 \\
\hline 2 & $\begin{array}{l}\text { 座る 02(道具)、食べる. } \\
\text { 飲む、見物、見る・観察 } \\
\text { 号る }\end{array}$ & & 休息 & 3 & 1.07 \\
\hline 3 & $\begin{array}{l}\text { 会話、奇りかかる、座る } \\
\text { 02(道具)、立つ、座る } \\
\text { 01(身) }\end{array}$ & & 集まっている-休息 & 20 & 7.12 \\
\hline 4 & $\begin{array}{l}\text { 会話、立つ、座る 02(道 } \\
\text { 具)、寄りかか、荷物を } \\
\text { 持っ }\end{array}$ & & 集まっている-社会性 & 19 & 6.76 \\
\hline 5 & $\begin{array}{l}\text { 䮕ぐ・笑う、立つ、走る、 } \\
\text { 座る01(身)、見物、座 } \\
\text { る02(道具) }\end{array}$ & & 集まっている-イタズラ & 20 & 7.12 \\
\hline 6 & $\begin{array}{l}\text { 走る、騷ぐ・笑う、見物、 } \\
\text { 身体をぶつけ合う、類似 } \\
\text { 遊具遊び }\end{array}$ & $\begin{array}{l}\text { 二活動の中に } \\
\text { 北上 } \\
\text { 支配行為 }\end{array}$ & $\begin{array}{l}\text { 身体をぶつけ合う・ } \\
\text { イタズラ }\end{array}$ & 29 & 10.32 \\
\hline 7 & 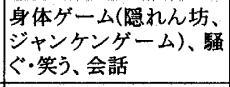 & \multirow{3}{*}{$\begin{array}{l}\text { 強い機能的 } \\
\text { 依存と活動別 } \\
\text { ○の支配 } \\
\text { 行為 }\end{array}$} & 身体グーム & 8 & 2.85 \\
\hline 8 & $\begin{array}{l}\text { カードゲーム、見物す } \\
\text { る、騥ぐ・笑う、座る } \\
01 \text { (体) }\end{array}$ & & 玩具ゲーム & 4 & 1.42 \\
\hline 9 & 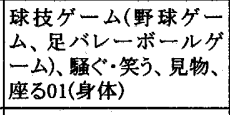 & & 球技ゲーム & 12 & 4.27 \\
\hline 10 & $\begin{array}{l}\text { 遊具利用遊び、騷ぐ・笑 } \\
\text { 万、見物、会話、座る }\end{array}$ & \multirow{5}{*}{$\begin{array}{l}\text { 活動別一つの } \\
\text { 支配行為 }\end{array}$} & $\begin{array}{l}\text { 遊 具 遊び・非遊具 } \\
\end{array}$ & 29 & 10.32 \\
\hline 11 & $\begin{array}{l}\text { ボール游び、騷ぐ・笑 } \\
\text { う、走る、見物 }\end{array}$ & & ボール遊び & 29 & 10.32 \\
\hline 12 & $\begin{array}{l}01 \text { (身体)、玩具遊び、騒 } \\
\text { ぐ・笑う、会話、見物、荷 } \\
\text { 物を持つ }\end{array}$ & & 玩具遊び & 12 & 4.27 \\
\hline 13 & $\begin{array}{l}\text { 自転車乗り、騷ぐ・笑う、 } \\
\text { 会話 }\end{array}$ & & 乗り物遊び & 28 & 9.96 \\
\hline 14 & 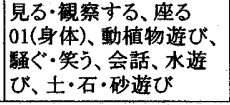 & & 操作・構築・自然遊び & 52 & 18.51 \\
\hline \multicolumn{4}{|c|}{ 合計 } & 281 & 100 \\
\hline
\end{tabular}

このような縮約作業によって分析した結果は、活動類型別にどのような 個別行為の発生頻度が多く、活動がどのような個別行為のパターンから 構成されているのかを判断することが、活動を定義し区分するために 重要であることが明らかとなった。

例えば、「歩く・徘䧃」は「休息」と似たような個別行為で構成されている が、「歩く・俳徊」は「歩く」、「ろうろする小、見る」の割合が高い。また、 「休息」は「座る」、「食べる」の割合が高いことが分かる。

「集まっている」に含まれる三つの活動類型も、「座る」、「見物」、 「会話」などの個別行為を共有している。よって「集まっている」を「歩く・ 俳䧃」、休息」、「イタズラ」などの他の活動から区別するのは、「立つ」、 「会話」などの行為に代表される社会性すなわち、社会的な交流の意味 が相対的に高い個別行為が見られることである。「集まっている」の三つ の類型は社会性の内包といら側面で共通しているが、これらを相互に 区別するのは、「集まっている-休息」には、「会話」、「寄りかかる」、 「座る」「立つ」などがみられること、「集まっている-社会性」は「会話」の 
割合が非常に高いこと、「集まっているーイタズラ」には、「騷ぐ・笑う」、 「立つ、「走る」などの行為がみられることである。

「集まっているーイタズラ」、身体をぶつけ合う・イタズラ」、玩具遊び」 活動は、多数の個別行為が均等に分布する。一方、他の活動は $4 、 5$ 種 類の個別行為群が高い割合で現われるのが特徴である。

「身体ゲーム、「球技ゲーム」、乗り物遊び」などの活動類型は、発生 頻度の高い行為の数が少なく、他の附随的行為群が一つの重要な行為 に附随する傾向を見せるといらように、支配行為の重要度が高く、行為群 の依存関係がみられる事例が多いと言える。

\section{3 行為脈絡と行為間依存関係}

支配行為に対する分析と同時に行為群の脈絡(発生脈絡)、行為間依 存関係を分析すれば、活動を定義して区分する作業がより明確になると 考える。

例えば、「集まっている」には、他の活動類型と比べて「立つ」、「座る」、 「きよろきよろ見回す」、「見物」「会話」などの行為が時系列的に相互に 依存せず発生しており、多数の行為者による並行的関係、同時多発的な 脈絡を見せる場合が多い。つまり、「集まっている」は、行為間の機能的な 依存関係より、社会的な依存関係が強く、時系列的には依存しないと 言える。

このような観点から、「集まっている」は、行為間の機能的、時系列的な 依存関係や主-従の依存関係を明確に見せる他の活動類型と区別でき ると考える。

また、「玩具ゲーム」、球技ゲーム」のような支配行為が強く現われる 活動類型は、他の活動類型と比べて機能的依存関係が強いと言える。

例えば、支配力が少ない行為群で構成された「歩く・徘䧃」「集まって いるーイタズラ」などの活動の中に、1つや2つの行為が機能的構造を離脱 しても、全体活動には大きな影響を与えないが、「ゲーム」などの少数の 支配力が強い行為群で構成された活動類型は、機能的構造の中で1つ や2つの行為が離脱すると活動自体が違う活動に変化してしまうことを 意味すると言える。

\section{4 支配行為}

活動をより明確に定義し、また相互区分するためには、一つの活動に 支配行為が存在するのか否か、支配行為として判断できる支配力のある 行為がいくつ位含まれているのかを特定する必要がある。したがって支 配行為を区別するために、行為間の従属関係を把握しなければならない。 「歩く・徘徊」、「休息」そして、三つの類型の「集まっている」には、同等な 重要度の様々な行為がみられるので、この中でーつの行為が支配行為 だとは評価しにくい。逆に、他の活動類型では活動がそれぞれの支配行 為で構成されており、残りは付随行為に区別することができる。

例えば、「身体ゲーム」などの活動は、「隠れん坊」のような一つの支配 行為に「見物」、騷ぐ・笑う」などの付随行為が従属されている構造で あるといえる。特に「イタズラ」は二つ以上の支配行為で構成されており、 他の活動と区別できる。

これは「集まっているーイタズラ」が、支配行為によって構成されていな いことと対照的である。したがって、「イタズラ」と「集まっているーイタズラ」 は、特定行為の支配力の差、相対的な重要度の差に対する観察によっ て区別できるといえる。

また、支配行為の重要度が高いことは、その行為の集中力が強いこと を意味する。例えば、「集まっているーイタズラ」に比べて「身体ゲーム」、 「球技グーム」などの活動類型は同時に発生する付随行為が少ないこと
が分かる。さらに、「ボール遊び」、乗り物遊び」、「遊具遊び」などは道具 や遊具を利用する一つの支配行為と騷ぐ・笑う」などの多数の付随行為 が従属されている構造であり、同時に発生する付随行為が「身体ゲーム」、 「球技ゲーム」より多いことが分かる。

\section{5 付随行為の影留力}

すべての個別行為は特定の意味を有するものであり、その重要度や 相互依存関係に関わらず人間の活動を構成する要素である。ただ、支配 行為と付随行為を区別するのは、付随行為の方が支配行為よりも、活動 の性格を決定する際の重要度が相対的に小さい点である。しかし、付随 行為そのものが影響力を持っていることも考えられる。

例えば、ブランコを利用する時の三つの活動について、一番目の例は 同時に発生する「座る」、「会話」、「見物」などの休息という性格をもつ 付随行為の影響によって「集まっている-社会性」に区別される。ブランコ 乗り以外に付随行為が見られない三番目の例は「遊具遊び」とはその 性格と意味が異なることが分かる。

したがって、支配行為と同時に、または時系列的に発生する付随行為 の特性によって、支配行為の重要度や支配力に差がうまれ、これに よって活動の性格に違いが現われると考えることができる。

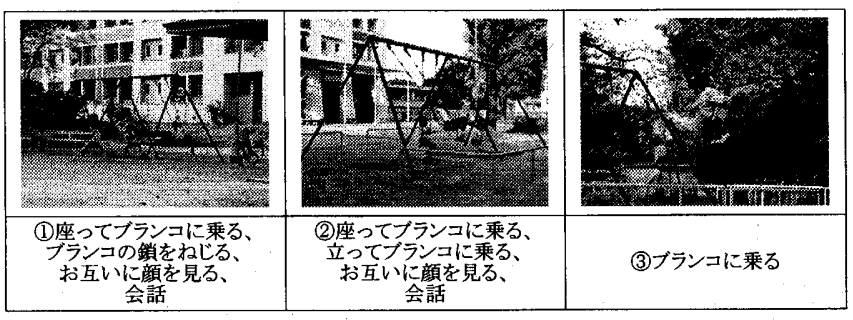

図11. 付随行為の影響力

\section{6. 個別行為と资源}

\section{1 個別行為の概念による资源の分析}

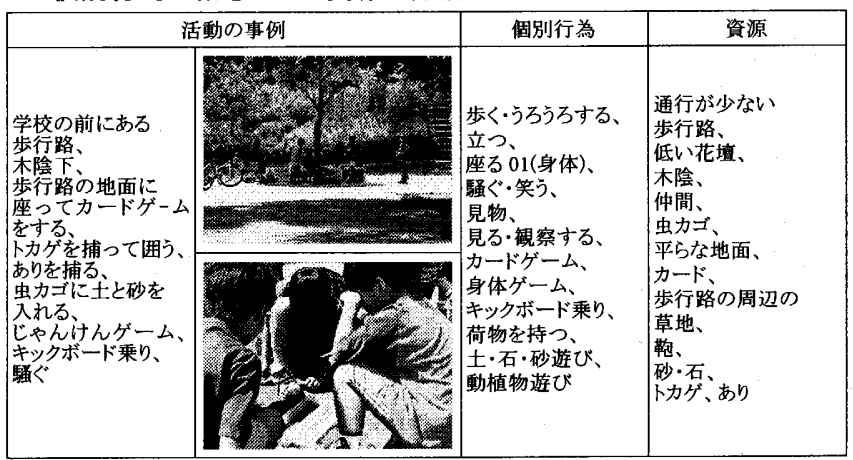

図12. 個別行為と資源の分析

一つの活動は、行為が脈絡、依存関係、重要度の側面で一定の関係 を結びながら、形成されることが分かった。しかし、個別行為を独立した 個体として区別しなければならないもうひとつの理由は、各個別行為が 固有な方式で資源 (環境要素) と相互に関連づけられて、個別的な意味 を持ち、他の個別行為と組み合わさって発生することである。

\section{2 活動亡瓷源との関係(表4)}

複雑な活動の構造を、個別行為を基に分析することで、建築環境に おいて“何を利用して何をするか”を明らかにすることができる。複雑な 活動を分析単位として用いる際に見失う恐れのある資源を、個別行為に よる分析では特定することができる。

個別行為を通じた活動分析は、活動に利用される資源にはどのような ものがあり、特にどのような資源の属性に影響を受けるのかを明らかに することに有効である。 
例えば、活動はその類型によって占有する空間の大きさと性格が異な る。「休息小、操作・構築・自然遊び」のような活動は、とても小さくて限定 された空間のみを利用して発生するが、「ボール遊び」の場合は広い 空間を利用する。このような分析ができるのは、「座る」、笑う、「会話」な どの個別行為と、「投げる」、「蹴る」などの個別行為によって利用される 空間が違うことを判別できるからである。また、自転車、椅子のような道具 的資源や遊具を利用して、どのような個別行為が発生するかを分析する ことによって、それを類型化することができると考えられる。資源を利用し た「座る」、会話」などの個別行為は「休息」として分類することができるが 同じ資源を利用した「椅子に乗って動く」、「自転車乗り」などのような活動 は、他の活動のカテゴリーに分類される。しかし、活動は多くの個別行為 で構成されていて、それぞれの重要度が異なることを既に分析したように、 資源も個別行為の重要度によってその性格を異にする。

上の例のように「休息」、「集まっている」などの活動は、「会話」、 「見物」、座る」、「寄りかかる」どの個別行為が発生するために、仲間 などの社会的資源と、空間の連結のような空間的特質資源を必要とする ことが分かる(表4、I ・IVの太枠内参照)。

また、「土・石・砂遊び」から類型化された「操作・構築・自然遊び」は、 砂と土のある限定された空閒と地面の状態などの空閒の質的・物理的 特性、ならびに玩具などの道具的資源に影響を受ける。そして、「身体 ゲーム、、球技ゲーム」などは、行為者である仲間がなければ、活動は 成り立たず、規則(Rule)がなくなれば全く異なる活動に変わる(表4、川の 太枠内参照)。「ボール遊び」、「球技ゲーム」、玩具遊び」、「玩具ゲー ム」などは、他の活動よりも道具的資源を必要とすることが分かる（表4、III の太枠内参照)。特に、道路に発生する「集まっているーイタズラ」、「ボー ル遊び」、「身体ゲーム」などの活動は通行が少ない時間、空間を利用し
て発生するので状況的資源が重要だと言える。以上より、活動と環境との 関係を分析するための道具として、個別行為は重要な役目を果たすこと が分かる。

7. 活動システムと資源を通した子どもの遊びの分析(図13)

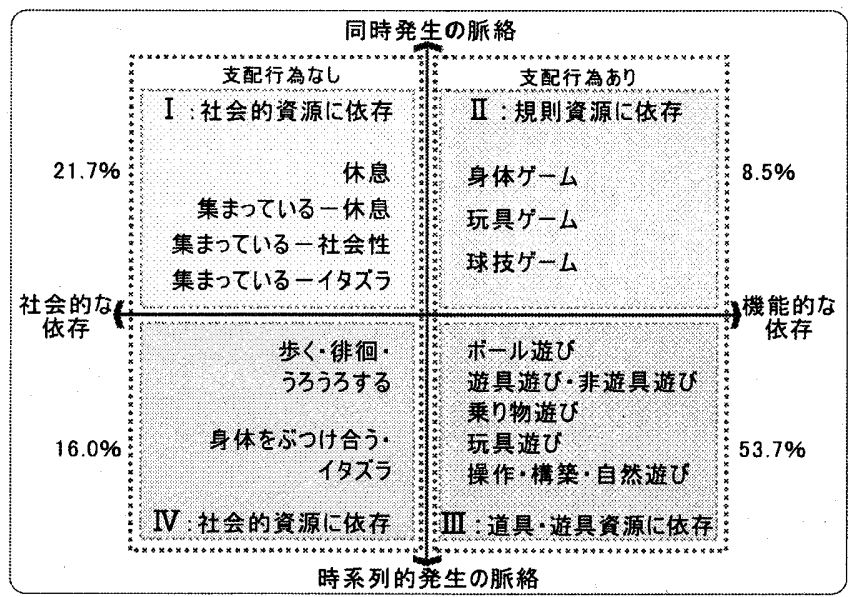

図13. 活動システムと資源を通した子どもの遊びの分析（図中の数値は表3より集計）

子どもの遊びについて、活動システムと資源を通した分析をすれば、 支配行為が強く、機能的に依存する遊び(図13におけるII+IIIの活動、 $62.2 \%)$ 多いことが分かる。特に、道具・遊具に依存する遊び(図13のIII、 53.7\%)が最も多く見られる。このような結果は、べトナムと韓国の子どもの 遊びを比較した研究3)同様の傾向を示している。また、社会的資源が 必要な「ゲーム(身体・玩具・球技、図 13 のII、8.5\%)」と「集まっている （休䕀・社会性・イタズラ、図13のI、21.7\%)」の活動が少ないことから、 子どもの遊びの必須要件である仲間が不足していると推察される。

表4. 活動と資源注9) との関係

（太枠は特徴的な活動と資源の関係を示す）

\begin{tabular}{|c|c|c|c|c|c|c|c|c|}
\hline $\begin{array}{l}\text { 凟源の影響 } \\
\text { による分類 }\end{array}$ & 活動 & $\begin{array}{l}\text { 重要な個別行為 } \\
\text { (発生頻度順序) }\end{array}$ & $\begin{array}{l}\text { 重要な空間の } \\
\text { 特質資源 }\end{array}$ & $\begin{array}{l}\text { 状況的 } \\
\text { 資源 }\end{array}$ & $\begin{array}{l}\text { 重要な } \\
\text { 社会的資源 }\end{array}$ & $\begin{array}{l}\text { 物理的な } \\
\text { 資源 }\end{array}$ & 道具的資源 & $\begin{array}{l}\text { 規則(Rule) } \\
\text { 資源 }\end{array}$ \\
\hline \multirow{6}{*}{ I, IV } & $\begin{array}{l}\text { 歩く・徘䧃・ } \\
\text { うろうろする }\end{array}$ & $\begin{array}{l}\text { 步く、うろうろする、見る・ } \\
\text { 観察する、荷物を持つ、会話 }\end{array}$ & 空間の連結 & $\begin{array}{l}\text { 弱い影響を } \\
\text { 受ける }\end{array}$ & \multirow{4}{*}{$\begin{array}{l}\text { 行為者、 } \\
\text { 社会的な } \\
\text { オブェタト }\end{array}$} & 弱い影響を受ける & 弱い影響を受ける & \multirow{6}{*}{$\begin{array}{l}\text { 弱い } \\
\text { 影響を } \\
\text { 受ける }\end{array}$} \\
\hline & 休息 & $\begin{array}{l}\text { 座る02(道具)、食べる・飲む、 } \\
\text { 見物、見る・濞察する }\end{array}$ & $\begin{array}{l}\text { プライバシー、 } \\
\text { 空間と知覚の連結 }\end{array}$ & $\begin{array}{l}\text { 弱い影響を } \\
\text { 受ける }\end{array}$ & & $\begin{array}{l}\text { 環境的な状態、 } \\
\text { 機能的な特性 }\end{array}$ & $\begin{array}{l}\text { 影響を受ける } \\
\text { (食べ物·飲み物) }\end{array}$ & \\
\hline & $\begin{array}{l}\text { 集まっている } \\
\text {-休息 }\end{array}$ & $\begin{array}{l}\text { 会話、寄りかかる、座る02 } \\
\text { (道具)、立つ、座る01(身体) }\end{array}$ & $\begin{array}{l}\text { プライバジー、 } \\
\text { 空間と知覚の連結 }\end{array}$ & 影響を受ける & & 環境的な状態 & $\begin{array}{l}\text { 影響を受ける } \\
\text { (食べ物·飲み物) }\end{array}$ & \\
\hline & $\begin{array}{l}\text { 集まっている } \\
\text { 一社会性 }\end{array}$ & $\begin{array}{l}\text { 会話、立つ、座る02(道具)、 } \\
\text { 奇りかが、、荷物を持つ }\end{array}$ & $\begin{array}{l}\text { 社会的な領域、 } \\
\text { 社会的な連結 }\end{array}$ & 影響を受ける & & $\begin{array}{l}\text { 影響を受ける } \\
\text { (墂境的な状態) }\end{array}$ & $\begin{array}{l}\text { 影響を受ける } \\
\text { (玩具、道具) }\end{array}$ & \\
\hline & $\begin{array}{l}\text { 集まってい } \\
\text { る-イタズラ }\end{array}$ & $\begin{array}{l}\text { 騒ぐ・笑う、立つ、走る、座る } \\
01 \text { (身)、見物、座る02(道具) }\end{array}$ & $\begin{array}{l}\text { 空關の連結、領城、 } \\
\text { 適切なスヘヘース }\end{array}$ & $\begin{array}{l}\text { 強い影響を } \\
\text { 受ける }\end{array}$ & \multirow{2}{*}{ 行為者 } & $\begin{array}{l}\text { 影響を受ける } \\
\text { (体体的な挑戦) }\end{array}$ & $\begin{array}{l}\text { 影響を受ける } \\
\text { (刓具、道具) }\end{array}$ & \\
\hline & $\begin{array}{l}\text { 身体をぶつけ } \\
\text { 合う・イダズ }\end{array}$ & $\begin{array}{l}\text { 走る、䮝ぐ•笑う、見物、 } \\
\text { 身体ぶつけ合い、類似遊具遊び }\end{array}$ & 適切なスペース & 影響を受ける & & $\begin{array}{l}\text { 影響を受ける } \\
\text { (何体的な挑戦) }\end{array}$ & $\begin{array}{l}\text { 影響を受ける } \\
\text { (玩具) }\end{array}$ & \\
\hline \multirow{3}{*}{ II } & 身体グーム & $\begin{array}{l}\text { 身体ゲーム(隠れん坊、ジャンケ } \\
\text { ソグーム)、騒ぐ+笑う、会話 }\end{array}$ & $\begin{array}{l}\text { 適切なスペース、領域 } \\
\text { (社会的·物理的) }\end{array}$ & 影響を受ける & \multirow{3}{*}{$\begin{array}{l}\text { 行為者、 } \\
\text { 重要な意味をもつ } \\
\text { 他者 }\end{array}$} & $\begin{array}{l}\text { 機能的な特性、 } \\
\text { 身体的な挑戦 }\end{array}$ & $\begin{array}{l}\text { 影響を受ける } \\
\text { (道具) }\end{array}$ & \multirow{3}{*}{$\begin{array}{l}\text { 強い } \\
\text { 影響を } \\
\text { 受ける }\end{array}$} \\
\hline & 玩具 グーム & $\begin{array}{l}\text { カードグーム、見物、騷ぐ・笑う、 } \\
\text { 座る01(身体) }\end{array}$ & $\begin{array}{l}\text { 適切なスペース、領城 } \\
\text { (社会的·物理的) }\end{array}$ & 影響を受ける & & 機能的な特性 & $\begin{array}{l}\text { 強い影響を受ける } \\
\text { (玩具) }\end{array}$ & \\
\hline & 球技ゲーム & $\begin{array}{l}\text { 球技ゲーム(野球ゲーム、足バレ } \\
\text { 一ボールゲーム)、䭷ぐ・笑う、 } \\
\text { 見物、座る01(身本) }\end{array}$ & $\begin{array}{l}\text { 適切なスペース、領域 } \\
\text { (社会的・物理的) }\end{array}$ & $\begin{array}{l}\text { 強い影響を } \\
\text { 受ける }\end{array}$ & & 機能的な特性 & $\begin{array}{l}\text { 強い影響を受ける } \\
\text { (ホホール、道具) }\end{array}$ & \\
\hline \multirow{5}{*}{ III } & $\begin{array}{l}\text { 遊具遊び- } \\
\text { 非遊具遊び }\end{array}$ & $\begin{array}{l}\text { 遊具利用遊び、騒ぐ・笑う、 } \\
\text { 見物、会話 }\end{array}$ & $\begin{array}{l}\text { 限定された空間 } \\
\text { (遊び場) }\end{array}$ & 影響を受ける & 行為者 & 強い影響を受ける & $\begin{array}{l}\text { 強い影響を受ける } \\
\text { (遊具) }\end{array}$ & \multirow{5}{*}{$\begin{array}{l}\text { 影響を } \\
\text { 受ける }\end{array}$} \\
\hline & ボール遊び & $\begin{array}{l}\text { ボール遊び、騒ぐ・笑う、走る、 } \\
\text { 見物 }\end{array}$ & $\begin{array}{l}\text { 適切なスペース、 } \\
\text { 限定された空間 }\end{array}$ & 影響を受ける & $\begin{array}{l}\text { 行為者、重要な } \\
\text { 意味をもつ他者 }\end{array}$ & 機能的な特性 & $\begin{array}{l}\text { 強い影響を受ける } \\
\text { (ボール) }\end{array}$ & \\
\hline & 玩具遊び & $\begin{array}{l}\text { 座る } 01(\text { 身体)、玩具遊び、騒ぐ・ } \\
\text { 笑う、会話、見物、荷物を持つ }\end{array}$ & $\begin{array}{l}\text { 適切なスペース、領域 } \\
\text { (社会的·物理的) }\end{array}$ & 影響を受ける & $\begin{array}{l}\text { 行為者、重要な } \\
\text { 意味をもう他者 }\end{array}$ & 環境的な状態 & $\begin{array}{l}\text { 強い影響を受ける } \\
\text { (玩具) }\end{array}$ & \\
\hline & 乗り物遊び & 自転車乗り、騒ぐ・笑う、会話 & $\begin{array}{l}\text { 適切なスペース、 } \\
\text { 限定された空間 }\end{array}$ & 影響を受ける & 行為者 & 環境的な状態 & \multirow{2}{*}{$\begin{array}{l}\text { 強い影響を受ける } \\
\text { (自転車) } \\
\\
\text { 強い影響を受ける } \\
\text { (玩具、道具) }\end{array}$} & \\
\hline & $\begin{array}{l}\text { 操作·構築· } \\
\text { 自然遊び }\end{array}$ & $\begin{array}{l}\text { 見る・観察する、座る01(身体)、 } \\
\text { 動植び物ひ、騷ぐ・笑う、会話、 } \\
\text { 水遊び、土·石・砂遊び }\end{array}$ & 限定された空問 & $\begin{array}{l}\text { 弱い影響を } \\
\text { 受ける }\end{array}$ & 行為者 & $\begin{array}{l}\text { 環境的な状態、 } \\
\text { 機能的な特性 }\end{array}$ & & \\
\hline
\end{tabular}




\section{8. 考察}

観察される複雑な活動は、何種類かの個別行為の依存または連結に より構成されている。人閒と環境との関係について、複雑な活動を分析 単位とするよりも、活動システムを通した活動の分析と、各個別行為で 利用される環境属性すなわち、資源を検討することが有効である。人間環境研究の中で最も基本になる人間の活動そのものを微細な単位に 分析することで、資源が活動の発現過程とどのような関係にあるのかを 明らかにし、活動-個別行為一資源の流れを提示できた。このことにより、 豊かな活動の誘発される環境を計画・デザインするために有効な行動セ ッティングを提示できると考えられる。個別行為の定義・分類と資源に関 するより包括的な課題、例えば、利用者の活動に必要とされる資源と、環 境が提供する資源との整合性に関する問題、資源の詳細な定義と類型 化などが、今後の研究課題である。さらに、活動システムと資源の概念を 通した、人間のための建築・環境デザインを検討することが必要である。

注

注1）「活動システム(Activity system)」に類似する用語や概念は、他の既往研究 で用いられているため、本研究における概念との相違を整理しておく必要がある。 まず、Chapin (1965)は、建物、近隣、都市の中でなされている活動の流れの構 成化を説明するため、「活動システム(Activity system)」の概念を使っている。 また、Perin (1970)は建築解析とデザインのための単位として「行動サーキット (Behavior circuit)」を用い、いくつかの行動サーキットから成る「活動システム (Activity system)」の概念を提示している。さらに、Reed の「行為システム群 (Action systems)」は、有機体と環境との関係を認知科学的な側面から説明した 知覚システムであると言える。一方、本研究での「活動システム」は、構造的・生 態学的な分析により、人間の活動がどのような構造であるかを明らかにすることを 目的としている。ただし、このような構造的分析から得ることは、上記既往研究と 同様に、有機体が環境との関係を通じてどのような反応を起こし、その反応がど のような行動パターンを粠成するのかについての知見であり、本研究も含めたい ずれの研究における概念も、人間行動と環境との関係を分析するためのツールと なり得るものである。

注2）資源の概念と分析方法は、文 3 を参照。

注 3) 人間行動が環境によって支配されるという建築決定論 (Architectural Determinism Lee,T.R)、環境が行動を制限するだけでなく機会も支えることである とする環境可能論(Environmental Possibilism,Porteus,1977)、環境の影響と人間 行動の蓋然性の折賁案である環境蓋然論 (Environmental Probalilism, Porteus,1977)、人間と環境はお互いに対立的、独立的なのではなくお互いに一 つの集合体であるとする相互作用論・相互浸透論(Transactionalism,Wapner,S) など、環境と行動との関係については多くの理論がある。

注4）Blumer は既存の人間の活動を分析する方法論は、社会的人間行動の分析 とは直接には関連がない、他の学問分野で作られたモデルを適用し、それを 社会学の研究対象にしなければ、人間像を探索する手助けにはならないと指摘 し、このような観点から綉導的概念(Sensitizing Concepts)という方法論を採用しな ければならないと述べている。誘導的概念は、現実世界を眺める最初の観察視 角に研究者が付与する最小限の概念的道具であり、理論的モデルとして、進む ことができる方向を設定できる。この研究の中で使われている人間の個別行為、 活動、活動システム、資源のような概念は、これらの関倸に対する基礎的なモデ ルだといえる。また、現場で観察される多様な現象をより組織的・效率的に理解 するための方法で、現状の理解から理論的な成果を導出するための一つの方法 論として活用することができると考えられる。

注5）児童心理学のいくつかの事例を除いた子どもの遊びに関する研究の大部分 は、“何をするのか”、“何をしながら遊ぶのか”という日常的な質問を行い、その 結果、各活動類型に付与される用語も日常的用語を主に使っている。ここでは 子どもの遊びに対する豊かな資料は、いくつかの日常的活動に縮約されている。 しかし、このような日常的な用語を使うことが問題なのではない。今まで日常的な 用語は、現実世界を表現する学術的用語としても充分に価値があった。問題は、 このように使われる言語がその中に含まれた人間の活動の豊かさを充分に表現 することができないことである。

注6)表5の通り、候補地の予備調查を行うことにより、子どもの遊びが多く観察され た地域・場所を最終的な調查対象地域に選定した。

注7）特定の場所において、複数の子どもに多様な活動が見られる場合、子どもの 集団の単位は、行為者 (Actor) と重要な意味をもつ他者 (Significant Others) 加 ら形成されるものと定義した。

注8）調查者が、事前に設定した観察経路に沿って移動し、移動時に観察される 全ての行動を詳細に記録する調查方法である。観察経路は、(1)経路上から調査 対象地区の全ての外部空間を見通せること、(2)観察対象空間が重複しないこと を条件に設定した。
注9）資源は社会的・物理的な環境の属性であり、遊びに使われる道具、状況など を含む包括的な概念である。これらの資源は、その性質により、(1)社会的な 資源: 遊びを一緒に行う仲間、遊びに関わる興味や目的を共有する友達を含む、 (2)物理的な資源: 空間的性質(空間の規模など)、物理的要素(Objects and Elements)、地面の属性など、物理的環境が有する特性を指す、(3)道具的資源： 子どもによって持ち込まれる道具(Brought-in Resources)として、社会的・物理的 環境要素に加えられるもの、(4)状況的資源: 遊びと関連づけられた状況、すなわ ち、妨害、危険など、遊びの断絶や統制に関わる空間的、時間的、社会的機会や 条件、(5)子どもと遊び仲間が合意し、決めた規則やルールであり、ダームの規則 のような社会的・慣習的な規篹や役目を含むる

\begin{tabular}{|c|c|c|c|c|c|}
\hline \multirow{2}{*}{\multicolumn{2}{|c|}{ 区別 }} & \multirow{2}{*}{\multicolumn{2}{|c|}{ 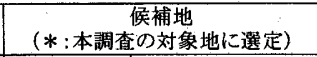 }} & \multicolumn{2}{|c|}{ 予備調查 } \\
\hline & & & & 調查期間 & 調查方法 \\
\hline \multirow{2}{*}{$\begin{array}{l}\text { 市街 } \\
\text { 地 }\end{array}$} & \begin{tabular}{|l} 
計画 \\
団地
\end{tabular} & $\begin{array}{l}\text { 千里NTK } \\
\text { おける高層 } \\
\text { 住宅団地 }\end{array}$ & $\begin{array}{l}* \text { 竹見台 } \\
\text { 新千里東町 }\end{array}$ & \begin{tabular}{|l|}
2003 年 9 月 29 日 \\
$\sim 10$ 月 28 日
\end{tabular} & \begin{tabular}{|l} 
平日・祝日の午後 \\
2 時〜6 時の間に \\
要な徍路・広場等
\end{tabular} \\
\hline & $\begin{array}{l}\text { 既成 } \\
\text { 市街地 }\end{array}$ & 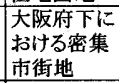 & $\begin{array}{c}* \text { 大阪市生野区 } \\
\text { 門真市石原地区 } \\
\text { 豊中市庄内地区 }\end{array}$ & $\begin{array}{l}2002 \text { 年 } 5 \text { 月 } 24 \text { 日 } \\
\sim 11 \text { 月 } 8 \text { 日 } \\
\end{array}$ & $\begin{array}{l}\text { を巡回し、子どもの } \\
\text { 活動の内容と位置 } \\
\text { を記録。 }\end{array}$ \\
\hline \multirow{2}{*}{ 自然・ } & $\begin{array}{l}\text { 計画 } \\
\text { 团地 }\end{array}$ & 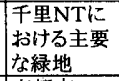 & $\begin{array}{l}* \text { 北千里公園 } \\
\text { 南千里公園 }\end{array}$ & $\begin{array}{l}2002 \text { 年 } 10 \text { 月 } 5 \text { 日 } \\
\sim 10 \text { 月 } 7 \text { 日 }\end{array}$ & $\begin{array}{l}\text { 平日または、祝日の } \\
\text { 午後 } 2 \text { 時〜 } 6 \text { 時の } \\
\text { 間に、公園、河川敷 }\end{array}$ \\
\hline & $\begin{array}{l}\text { 般 } \\
\text { 市街地 } \\
\end{array}$ & $\begin{array}{l}\text { 䈞都市 } \\
\text { 上京区 } \\
\text { 左京区 }\end{array}$ & 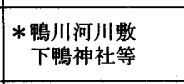 & \begin{tabular}{|l}
2002 年 8 月 15 日 \\
$\sim 8$ 月 17 日
\end{tabular} & $\begin{array}{l}\text { 等を巡回し、子ども } \\
\text { の活動の内容と } \\
\text { 位直を記録。 }\end{array}$ \\
\hline \multirow[b]{2}{*}{ |道路 } & \begin{tabular}{|l} 
桩画 \\
団地 \\
\end{tabular} & \begin{tabular}{|l|} 
NTK \\
歩行者 \\
尃用街路
\end{tabular} & \begin{tabular}{|l}
$*$ *多摩NT \\
幕ベイタウン
\end{tabular} & $\begin{array}{l}2003 \text { 年 } 5 \text { 月 } 30 \text { 日 } \\
\sim 6 \text { 月 } 1 \text { 日 } \\
\end{array}$ & 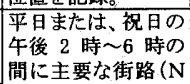 \\
\hline & \begin{tabular}{|l} 
既成 \\
市街地
\end{tabular} & $\begin{array}{l}\text { 大阪市 } \\
\text { 中央区 } \\
\text { 空碬地区 }\end{array}$ & *空堀地区 & 2003 年 8 日 7 日 & 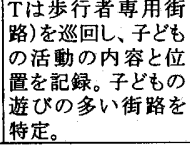 \\
\hline
\end{tabular}

\section{参考文献}

1）エドワード・S:リード著: 細田直哉訳、アフォーダンスの心理学; 生態心理学へ の道、新曜社、2000

2) Lang, Jon T.: Creating architectural theory, the role of the behavioral sciences in environmental design, New York, Van Nostrand Reinhold Co. 1987

3）尹 俊到、閔 丙吴、木多 道宏、舟橋 國男: ベトナムの居住地と韓国の集合 住宅団地における子どもの外部空間行為の比較研究、日本建築学会計画系論 文集、No.576、pp59-66、2004.02

4）水月 昭道、南 博文：下校路に見られる子どもの道草遊びと道環境との関係、 日本建筑学会計画系論文集、No.574、pp61-68、2003.12

5) Barker, R.:Ecological psychology, Concepts and methods for studying the environment of human behavior, Stanford, CA, Stanford University Press, 1968

6）日本建築学会編、人間-環境系のデザイン、彰国社、1997

7) Moore, R. \& Young, D:Childhood outdoors, Toward a social ecology of the landscape, In I. Altman \& J. Wohlwill (eds.), Human behavior and environment, Vol.3, Children and the environment, New York, Plenum, 1978.

8) Wohlwill, J. F. \& Heft, H.:The physical environment and the development of the child. In D., Stokols \& I. Altman (eds.), Handbook of environmental psychology. Vol.1, New York, John Wiley \& Sons. 1987

9) Piaget: Play, dream and imagination in childhood, New York: Norton, 1951

10) Robbin C. Moore: Childhood's Domain. Play and Place in Child Development, MIG communication, 1990

11）谷口 新、仙田 渵、矢田 努、水谷 考治: あそび環境要素からみた計画集 合住宅地におけるこどものあそび構造、日本建築学会計画系論文集、No.518、 pp89-96、1999.04

12) Urie Bronfenbrenner: The Ecology of Human Development, Harvard University Press, 1979

13) Herbert Blumer: Symbolic interactionism: perspective and method, Englewood Cliffs, N.J.: Prentice-Hall, 1969

14）三輪 律江、仙田 満、矢田 努：こどものあそび空間発生性に関する研究、 日本建築学会計画系論文集、No.539、pp187-194、2001.01

15）神田 徳蔵、堀川顥彦：道路の生活 (遊び場)化に関する基礎的考察、 日本建築学会大会学術講演梗概集、pp2099-2100、1983.09

16) Jennifer Masson: Qualitative Researching, Sage Publications, 1996

17) Zeisel, John: Inquiry by design, Tools for environment-behavior research, New York, Cambridge University Press, 1981

18）閔 丙昊：「ラピュタ」を捜して、子どものために居住団地の計画、世進社 2001

19) Barbara Sommer, Robert Sommer: A practical guide to behaviora research: tools and techniques, New York: Oxford University Press, 1991 